\title{
Effect of Sowing Dates on the Bacterial Leaf Spot of Bottle Gourd and Pumpkin Caused by Xanthomonas cucurbitae
}

\author{
Arpana Sharma ${ }^{1}$, Kumud Jarial ${ }^{1} \geq 0$, R. S. Jarial' ${ }^{1}$ and Deepa Sharma ${ }^{2}$ \\ ${ }^{1}$ Dept. of Plant Pathology, ${ }^{2}$ Dept. of Vegetable Science, College of Horticulture and Forestry, Dr. Yashwant Singh Parmar \\ University of Horticulture and Forestry, Neri, Hamirpur, Himachal Pradesh (177 001), India
}

Open Access

Corresponding $邓$ kumudvjarial@rediffmail.com

0000-0003-1965-0890

\begin{abstract}
A $\mathrm{n}$ experiment was conducted at Experimental Farm, College of Horticulture and Forestry, Neri, Hamirpur during May 2019 to October, 2019 cropping season to study the effect of different sowing dates viz., $17^{\text {th }}$ May $\left(1^{\text {st }}\right), 7^{\text {th }}$ June $\left(2^{\text {nd }}\right), 27$ June $\left(3^{\text {rd }}\right)$ and $17^{\text {th }}$ July $\left(4^{\text {th }}\right)$ on the development of bacterial leaf spot of bottle gourd and pumpkin caused by Xanthomonas cucurbitae. It was observed that the mean disease severity in both bottle gourd and pumpkin crops decreased with delay in the date of sowing from mid May (40.15 and 31.73\%, respectively) to the end of June (27 June, 31.65 and 27.06\%, respectively) or mid July (17 July, 23.32 and $20.13 \%$, respectively). The disease incidence was also found to be minimum in the fourth (31.31\%) and third (39.60\%) dates of sowing in case of bottle gourd fruits and no incidence of the bacterial spot was recorded in case of pumpkin fruits. In the case of bottle gourd, the expected yield loss was minimum in crops sown mid July (31.44\%) while in pumpkin, the fruit yield was more in mid July $\left(9.59 \mathrm{~kg}\right.$ vine $\left.{ }^{-1}\right)$ sown crop in comparison to mid May and early June sown crops. So, it was concluded that late June and mid July sown crops of both bottle gourd and pumpkin are less vulnerable to the disease leading to reduced crop losses and higher yield.
\end{abstract}

KEYWORDS: Bacterial leaf spot, cucurbits, sowing dates, Xanthomonas cucurbitae

Citation (VANCOUVER): Sharma et al., Effect of Sowing Dates on the Bacterial Leaf Spot of Bottle Gourd and Pumpkin Caused by Xanthomonas cucurbitae. International Journal of Bio-resource and Stress Management, 2022; 13(1), 106-113. HTTPS://DOI.ORG/10.23910/1.2022.2395a.

Copyright: @ 2022 Sharma et al. This is an open access article that permits unrestricted use, distribution and reproduction in any medium after the author(s) and source are credited.

Data Availability Statement: Legal restrictions are imposed on the public sharing of raw data. However, authors have full right to transfer or share the data in raw form upon request subject to either meeting the conditions of the original consents and the original research study. Further, access of data needs to meet whether the user complies with the ethical and legal obligations as data controllers to allow for secondary use of the data outside of the original study.

Conflict of interests: The authors have declared that no conflict of interest exists.

RECEIVED on $02^{\text {nd }}$ June 2021 RECEIVED in revised form on $24^{\text {th }}$ December 2021 ACCEPTED in final form on $20^{\text {th }}$ January 2022 PUBLISHED on $31^{\text {st }}$ January 2022 


\section{INTRODUCTION}

$\mathrm{B}$ acterial spot of cucurbits, impelled by Xanthomonas cucurbitae (Ex. Bryan) Vauterin et al., 1995 (Syn. $X$. campestrispv. cucurbitae) is one of the most significant maladies of bottle gourd and pumpkin (Jarial et al., 2011 and Babadoost and Ravanlou, 2012). This bacterial disease was first reported as a bacterial spot on Hubbard squash in New York in 1926 (Bryan, 1930). Subsequently, the disease was identified in various cucurbits like squash from Brazil (Robbset al., 1972), Argentinia (Alippi, 1989) and North Central United States (Liu et al., 2016); cucumber from Queensland, Australia (Anonymous, 1975), Brazil (Maringoni et al., 1988), India (Sinha, 1989) and China (Li, 1990); watermelon from Georgia (Dutta et al., 2013) and Seychelles (Pruvost et al., 2009); prince melon from Hokuriku (Taketani et al., 1976); pumpkin from the United States (William and Zitter, 1996), Reunion Island (Pruvost et al., 2009), Nepal (Lamichhane et al., 2010), Ontario, Canada (Trueman et al., 2014), North Central United States (Liu et al., 2016) and Italy (Altin et al., 2020) and bottle gourd from India (Jarial et al., 2011). This bacterial disease has been accounted for causing enormous losses in cucurbits and approximately $50-60 \%$ disease severity reaches at the time of storage of fruit (Larazev, 2009). Jarial et al. (2011) reported 10.07 to $70.61 \%$ yield losses in the case of bottle gourd. About $90 \%$ of losses were recorded in the case of pumpkin by Salamanca (2014).

Bottle gourd and pumpkin are two important cucurbitaceous crops grown for kitchen and commercial purpose in sub tropical zone of Himachal Pradesh. The bottle gourd crop is so badly affected with this disease that the farmers have either stopped its commercial cultivation or reduced to a considerable level. In pumpkin, although the fruits are not affected much but, the foliar infection leads to reduction in plant vigour and fruit yield (Jarial et al., 2018). An effective technique in an area should be to devise an integrated disease management methodology (Babadoost and Zitter, 2009). Most bacterial diseases of plants are managed using integrated strategies (Jurgens and Babadoost, 2013). Jarial et al. (2015) have suggested a strategy for management of bacterial spot in bottle gourd including cultural methods, seed treatments or foliar sprays. Management strategy for any bacterial disease requires a complete knowledge of disease epidemiology so as to identify the most vulnerable stage of the host and timing of adaptation of management strategy (Sundin et al., 2016). Sowing dates of bottle gourd and pumpkin might affect the disease severity and disease incidence of bacterial spot of cucurbits. But, there is no literature available on this aspect. However, many workers have worked on effect of sowing dates on the development of other bacterial diseases (Raut et al., 2010; Rafi et al., 2013;
Amin et al., 2017). The sowing time of any crop depends upon the local climatic conditions as well as the market demand of the commercial product. The climate favourable for crop cultivation is generally favourable for the pathogens too. While talking about bacterial spot in cucurbits, the disease is favoured by warm and humid climate and spreads through rain splashes (Babadoost, 2012). So variation in sowing time of the crops in such a way that the disease spread is minimized can definitely affect the final disease level and crop yields. Bottle gourd and pumpkin being tropical crops can be grown in a wide range of temperature ranging between 18 to $35^{\circ} \mathrm{C}$ (Dhaliwal, 2017). Therefore, present studies were conducted with an objective to study the effect of sowing dates of bottle gourd and pumpkin on disease development.

\section{MATERIALS AND METHODS}

$\mathrm{T}$ he study was conducted at Experimental Farm, Department of Plant Pathology, College of Horticulture and Forestry, Neri, Hamirpur, Himachal Pradesh, India $\left(31.68^{\circ} \mathrm{N}\right.$ and $\left.76.52^{\circ} \mathrm{E}\right)$ in a randomized block design with six replications each in which commercial hybrids of bottle gourd (hybrid 1) and pumpkin (hybrid 1) were planted at 20 days interval on four different dates of sowing starting from $17^{\text {th }}$ May 2019 to $17^{\text {th }}$ July 2019 under natural epiphytotic condotions. The first sowing was done on $17^{\text {th }}$ May, 2019 followed by the second on $7^{\text {th }}$ June 2019 the third on $27^{\text {th }}$ June 2019 and the fourth on $17^{\text {th }}$ July 2019. Data on disease severity (\%) were recorded at seven days intervals starting from the first day of symptom appearance in each sowing date upto 70 days after disease appearance as per scale given by Jarial et al. (2011). Further, the disease severity index was calculated as per the formula given by McKinney (1923). The data were further subjected for the calculation of apparent infection rate (per unit per day) and area under disease progress curve (AUDPC) as per the formulae given by Van der Plank (1963) and Shanner and Finney (1970), respectively. In case of fruit infection, data were recorded in terms of disease incidence by Johnston and Booth (1983).

Harvesting in both the crops started from July, 2019 in different dates of sowing and lasted upto October, 2019. Data were also recorded in terms of the total number of fruits observed and harvested in each vine and yield was also recorded in terms of fruit weight per vine $(\mathrm{kg})$. Based on these data, average fruit weight was calculated and expected yield per vine was calculated as follows:

Expected yield per vine=Average fruit weight $\times$ Total number of fruits on the vine

Further, expected yield loss (\%) was calculated as per the formula given below:

Expected yield loss $(\%)=($ Expected yield - Actual yield $) /$ 
(Expected yield) $\times 100$

The experiment was conducted in the field in randomized block design with six replications for each treatment and statistically analyzed by using online software OPSTAT.

\section{RESULTS AND DISCUSSION}

A $\mathrm{s}$ is clear from Figure 1 that initially up to 21 days after disease appearance, the disease severity level in all the sowing dates was almost equal. After 28 days of disease appearance, the disease severity level was highest on the third date of sowing. After that, the disease severity in the first and second dates of sowings increased drastically and at the end, the level was recorded to be highest on the first date of sowing i.e. the crop sown on $17^{\text {th }}$ May followed by the crop sown on $7^{\text {th }}$ June.

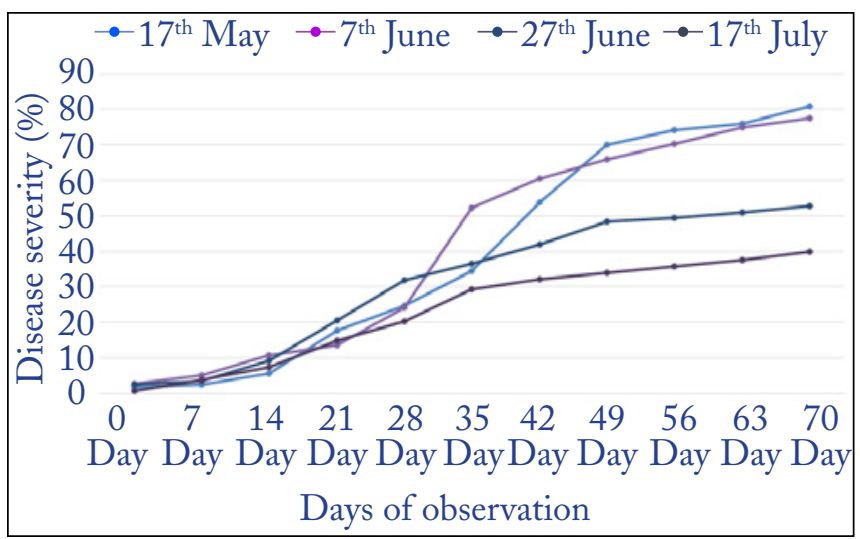

Figure 1: Progress of bacterial leaf spot of bottle gourd as influenced by different dates of sowing

The data presented in Table 1 revealed that in the case of bottle gourd, minimum disease severity (23.32\%) was recorded in the fourth date of sowing followed by third $(31.65 \%)$, first $(40.15 \%)$ and second $(41.64 \%)$ dates of sowing. Irrespective of the date of sowing, mean disease severity was minimum (1.99\%) on the first day of observation i.e. 0 days after disease appearance, which increased significantly after each interval of observation and reached its maximum (62.77\%) on the last day of observation i.e. 70 days after disease appearance.

Body of the table revealed that significantly minimum $(0.82 \%)$ disease severity was recorded in the fourth date of sowing on the first day of observation i.e. 0 days after disease appearance followed by first (1.66\%), third (2.54\%) and second (2.92\%) date of sowing on the first day of observation. The disease severity recorded after 21 days of disease appearance on third date of sowing $(20.54 \%)$ was statistically at par with disease severity recorded on the fourth date of sowing after 28 days of disease appearance (20.38\%). However, significantly maximum disease severity $(80.83 \%)$ was recorded on the first date of sowing after 70 days of disease appearance followed by disease severity in second (77.41\%), third (52.87\%) and fourth (39.97\%) date of sowing after the same duration. Intermediate disease severity was recorded on the rest of the days of observation in four different dates of sowing. As far as the apparent infection rate was concerned, it was significantly minimum $\left(0.055\right.$ unit $^{-1}$ day $\left.^{-1}\right)$ on the third date of sowing followed by the fourth $\left(0.058\right.$ unit $^{-1}$ day $\left.^{-1}\right)$ date of sowing. However, a significantly maximum apparent infection rate $\left(0.078\right.$ unit $^{-1}$ day $^{-1}$ ) was recorded on the first date of sowing followed by that $\left(0.070\right.$ unit $^{-1}$ day $\left.^{-1}\right)$ on the second date of sowing. A similar trend was observed in all dates of sowing in terms of AUDPC which was significantly minimum (16.78) on the fourth date of sowing followed by the third (22.27) date of sowing. However, significantly maximum AUDPC (32.10) was recorded on the second date of sowing followed by that on the first date of sowing (27.93). The data presented in Table 2 reveal the disease incidence recorded in bottle gourd fruits in the plants sown on different dates of sowing along with the yield per vine $(\mathrm{kg})$ and expected yield loss in each date of sowing. It is clear from the table that disease incidence in terms of fruit rot was significantly highest $(52.17 \%)$ in plants sown on the first date followed by that in second (45.13\%), third (39.60\%) and fourth (31.31\%) dates of sowing. The total number of fruits vine ${ }^{-1}$ was observed to be significantly maximum (14.33) in plants sown on the last date of sowing followed by third (12.67), first (11.50) and second (10.33) dates of sowing. However, the number of healthy fruits harvested and yield vine ${ }^{-1}$ were found to be significantly maximum (9.83 and $6.17 \mathrm{~kg}$ ) in plants sown on $17^{\text {th }}$ July 2019 followed by those sown on $27^{\text {th }}$ June ( 7.50 and $4.70 \mathrm{~kg}), 7^{\text {th }}$ June (5.67 and $3.42 \mathrm{~kg}$ ) and $17^{\text {th }}$ May 2019 $(5.50$ and $3.11 \mathrm{~kg})$. Average fruit weight calculated on this basis was found to be significantly maximum $(0.628 \mathrm{~kg})$ in plants sown on the fourth date. Based on the total number of fruits vine ${ }^{-1}$ and average fruit weight, the expected yield $v^{\text {vine }}{ }^{-1}$ was calculated which was found to be significantly maximum $(9.00 \mathrm{~kg})$ in the fourth date of sowing followed by third $(7.92 \mathrm{~kg})$ and second $(6.24 \mathrm{~kg})$ date of sowing. From these calculations, expected yield loss was further calculated which was found to be maximum (52.30\%) in crop sown on $17^{\text {th }}$ May followed by that sown on $7^{\text {th }}$ June $(45.19 \%), 27^{\text {th }}$ June (40.65\%) and $7^{\text {th }}$ July (31.44\%).

Local climatic conditions and market demand of crop generally affect the sowing time of a particular crop directly. Also, the climate favourable for crop cultivation is generally favourable for the pathogens too. Bottle gourd and pumpkin being tropical crops can be grown in a wide range of temperature ranging between 18 to $35^{\circ} \mathrm{C}$ (Dhaliwal, 2017). While talking about bacterial spot in cucurbits, the disease is favoured by warm and humid climate and spreads through rain splashes (Babadoost, 2012). So variation in sowing time of the crops in such a way that the disease spread is 


\begin{tabular}{|c|c|c|c|c|c|c|c|c|}
\hline \multirow[t]{2}{*}{ Date of sowing } & \multicolumn{8}{|c|}{ Disease severity (\%) after the days of appearance } \\
\hline & 0 & 7 & 14 & 21 & 28 & 35 & 42 & 49 \\
\hline 17 $7^{\text {th }}$ May, 2019 & $\begin{array}{c}1.66 \\
(7.39)\end{array}$ & $\begin{array}{c}2.59 \\
(9.26)\end{array}$ & $\begin{array}{c}5.56 \\
(13.64)\end{array}$ & $\begin{array}{c}17.67 \\
(24.85)\end{array}$ & $\begin{array}{c}24.63 \\
(29.74)\end{array}$ & $\begin{array}{c}34.46 \\
(35.93)\end{array}$ & $\begin{array}{c}53.94 \\
(47.24)\end{array}$ & $\begin{array}{c}70.12 \\
(56.84)\end{array}$ \\
\hline $7^{\text {th }}$ June, 2019 & $\begin{array}{c}2.92 \\
(9.84)\end{array}$ & $\begin{array}{c}5.17 \\
(13.14)\end{array}$ & $\begin{array}{c}10.80 \\
(19.18)\end{array}$ & $\begin{array}{c}13.55 \\
(21.59)\end{array}$ & $\begin{array}{c}24.19 \\
(29.45)\end{array}$ & $\begin{array}{c}52.21 \\
(46.24)\end{array}$ & $\begin{array}{c}60.55 \\
(51.07)\end{array}$ & $\begin{array}{c}65.83 \\
(54.20)\end{array}$ \\
\hline $27^{\text {th }}$ June, 2019 & $\begin{array}{c}2.54 \\
(9.18)\end{array}$ & $\begin{array}{c}3.55 \\
(10.85)\end{array}$ & $\begin{array}{c}9.30 \\
(17.75)\end{array}$ & $\begin{array}{c}20.54 \\
(26.93)\end{array}$ & $\begin{array}{c}32.00 \\
(34.43)\end{array}$ & $\begin{array}{c}36.48 \\
(37.14)\end{array}$ & $\begin{array}{c}42.06 \\
(40.41)\end{array}$ & $\begin{array}{c}48.40 \\
(44.06)\end{array}$ \\
\hline $17^{\text {th }}$ July, 2019 & $\begin{array}{c}0.82 \\
(5.22)\end{array}$ & $\begin{array}{c}3.96 \\
(11.47)\end{array}$ & $\begin{array}{c}7.53 \\
(15.92)\end{array}$ & $\begin{array}{c}15.00 \\
(22.77)\end{array}$ & $\begin{array}{c}20.38 \\
(26.83)\end{array}$ & $\begin{array}{c}29.38 \\
(32.81)\end{array}$ & $\begin{array}{c}32.26 \\
(34.59)\end{array}$ & $\begin{array}{c}33.85 \\
(35.56)\end{array}$ \\
\hline Overall mean & $\begin{array}{c}1.99 \\
(7.91)\end{array}$ & $\begin{array}{c}3.81 \\
11.18)\end{array}$ & $\begin{array}{c}8.30 \\
(16.62)\end{array}$ & $\begin{array}{c}16.70 \\
(24.04)\end{array}$ & $\begin{array}{c}25.30 \\
(30.11)\end{array}$ & $\begin{array}{c}38.13 \\
(38.03)\end{array}$ & $\begin{array}{c}47.20 \\
(43.33)\end{array}$ & $\begin{array}{c}54.55 \\
(47.67)\end{array}$ \\
\hline \multicolumn{9}{|c|}{$\mathrm{CD}(p=0.05) \mathrm{SE}(\mathrm{d})$} \\
\hline \multicolumn{3}{|c|}{ Date of sowing (DS) } & \multicolumn{6}{|c|}{0.08} \\
\hline \multicolumn{3}{|c|}{ Day of observation (Do) } & \multicolumn{6}{|c|}{0.14} \\
\hline \multicolumn{3}{|c|}{ Interaction $(\mathrm{DO} \times \mathrm{DS})$} & \multicolumn{6}{|c|}{0.29} \\
\hline
\end{tabular}

Table 1: Continue...

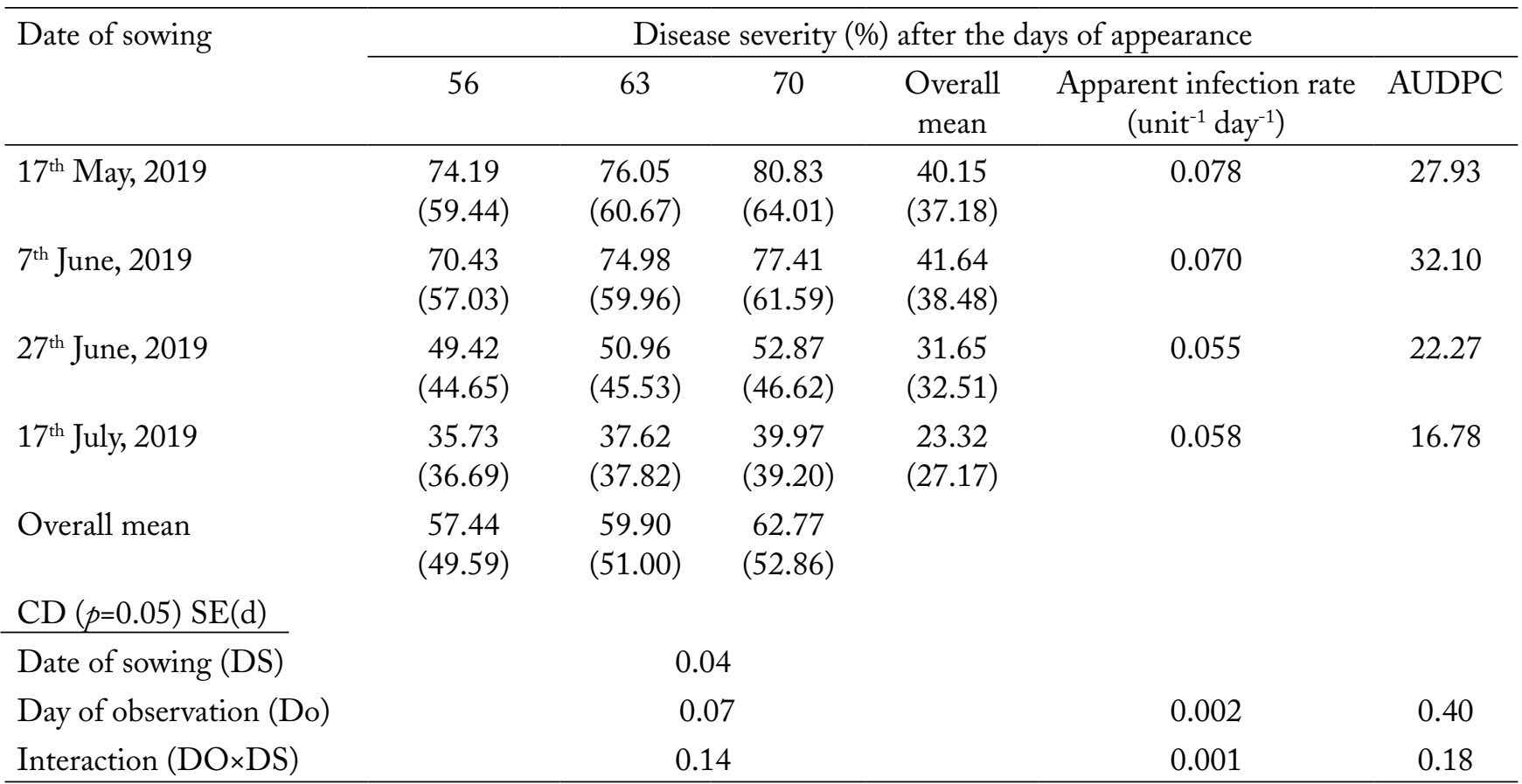

Figures in parentheses are arcsine transformed values

minimized can definitely affect the final disease level and crop yields. So, during the present studies, the sowing dates starting from $17^{\text {th }}$ May to $17^{\text {th }}$ July were evaluated to see their effect on disease development and crop yield. The results of studies revealed that disease severity of bacterial spot in bottle gourd was maximum in crop sown in mid May (1 $17^{\text {th }}$ May) and early June ( $7^{\text {th }}$ June) as compared to those sown at end of June ( $27^{\text {th }}$ June) and mid July ( $17^{\text {th }}$ July).
The apparent infection rate was also lesser in late sown crop than the early sown crops. This decrease in apparent infection rate can be attributed to the fact that the causal bacterium spreads through rain splashes from one plant to another (Goldberg, 2012) and the mid July sown crop completed most of its cropping period after the rainy season was over, thus reducing the rate of spread of disease. As far as yield of bottle gourd was concerned it was also more in 


\begin{tabular}{lccccccc}
\hline Table 2: Effect of sowing dates on the incidence of bacterial leaf spot and yield in bottle gourd \\
\hline Date of sowing & $\begin{array}{c}\text { Disease } \\
\text { incidence } \\
(\%)\end{array}$ & $\begin{array}{c}\text { Total no. of } \\
\text { fruits observed } \\
\text { vine }^{-1} \text { (avg.) }\end{array}$ & $\begin{array}{c}\text { Number of } \\
\text { healthy fruits } \\
\text { harvested (avg.) }\end{array}$ & $\begin{array}{c}\text { Actual } \\
\text { yield (kg) } \\
\text { vine }^{-1}\end{array}$ & $\begin{array}{c}\text { Average } \\
\text { fruit weight } \\
(\mathrm{kg})\end{array}$ & $\begin{array}{c}\text { Expected } \\
\text { yield (kg) } \\
\text { vine }^{-1}\end{array}$ & $\begin{array}{c}\text { Expected } \\
\text { yield loss } \\
(\%)\end{array}$ \\
\hline $17^{\text {th }}$ May, 2019 & 52.17 & 11.50 & 5.50 & 3.11 & 0.567 & 6.52 & 52.30 \\
$7^{\text {th }}$ June, 2019 & 45.13 & 10.33 & 5.67 & 3.42 & 0.604 & 6.24 & 45.19 \\
$27^{\text {th }}$ June, 2019 & 39.60 & 12.67 & 7.50 & 4.70 & 0.626 & 7.92 & 40.65 \\
$17^{\text {th }}$ July, 2019 & 31.31 & 14.33 & 9.83 & 6.17 & 0.628 & 9.00 & 31.44 \\
$\mathrm{SE}(\mathrm{d})$ & 1.56 & 0.52 & 0.35 & 0.21 & 0.001 & 0.31 & \\
$\mathrm{CD}(p=0.05)$ & 3.35 & 1.12 & 0.77 & 0.47 & 0.002 & 0.67 & \\
\hline
\end{tabular}

late June and mid-July sown crops as compared to earlier sown crops. A definite relationship between disease level and yield could be visualized as the yield was more in those treatments in which disease levels were lesser. In the case of bottle gourd, expected yield loss was also calculated and it was also found to be minimum in crops sown in late June and mid-July. This reduction in yield in heavily infected vines can be attributed to the fact that disease affects the foliage of the plants thus directly reducing the photosynthetic area, ultimately leading to lesser fruit production. Such types of studies have not been conducted to date on this disease in any pathosystem, so the results cannot be compared with any available literature. However, many workers have studied the effect of sowing dates on the diseases caused by other Xanthomonas. The results obtained during present studies are in accordance with Raut et al. (2010) who reported that incidence of bacterial blight of cotton was maximum in crop sown earlier i.e. on 27 June (first), $7^{\text {th }}$ July $\left(2^{\text {nd }}\right)$ and $17^{\text {th }}$ July (third). The progress of the disease in pumpkin crop sown on four different dates has been presented in Figure 2. As is clear from Figure 2 that initially up to 14 days after disease appearance, the disease severity level in all the sowing dates was almost equal. After 21 days of disease appearance, the disease severity level was highest on the third date of sowing. After that, the disease severity in the

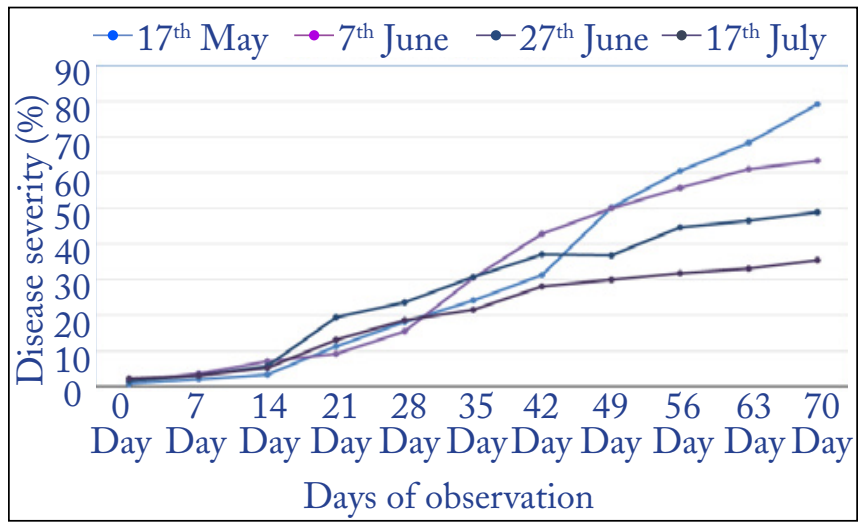

Figure 2: Progress of bacterial leaf spot of pumpkin as influenced by different dates of sowing first and second dates of sowings increased drastically and at the end, the level was recorded to be highest on the first date of sowing i.e. the crop sown on $17^{\text {th }}$ May followed by the crop sown on $7^{\text {th }}$ June. However, the disease level was recorded to be lowest on the fourth date of sowing i.e. the crop sown on $17^{\text {th }}$ July

The data in Table 3 revealed that in the case of pumpkin, irrespective of days of observation, significantly minimum mean disease severity $(20.13 \%)$ was recorded in the fourth date of sowing followed by the third $(27.06 \%)$ date of sowing. However, the maximum mean disease severity (31.73\%) was recorded on the first date of sowing which was statistically at par with the mean disease severity recorded in the second (30.92\%) date of sowing. Irrespective of the date of sowing, mean disease severity was minimum (1.50\%) on the first day of observation i.e. 0 daysafter disease appearance which increased significantly at each interval of observation and reached the maximum (56.66\%) on the last day of observation i.e.70 days after disease appearance. Further, the interaction of date of sowing and days of observation revealed that significantly minimum $(0.72 \%)$ disease severity was recorded on the first day of observation on the first date of sowing which was statistically at par with disease severity on the first day of observation in second (1.55\%) and third (1.57\%) dates of sowing as well as after 7 days of disease appearance in the first date of sowing (2.13\%). However, maximum disease severity (79.22\%) was recorded on the first date of sowing after 70 days of disease appearance followed by disease severity $(63.35 \%)$ in second, third (48.75\%) and fourth $(35.33 \%)$ dates of sowing after the same duration. An intermediate level of disease severity was recorded on the rest of the days on four different dates of sowing.

It is evident from the data that the apparent infection rate was significantly minimum $\left(0.047\right.$ unit $^{-1}$ day $\left.^{-1}\right)$ on the fourth date of sowing followed by the third $\left(0.058\right.$ unit $^{-1}$ day $\left.^{-1}\right)$ date of sowing. However, the apparent infection rate was recorded to be significantly maximum $\left(0.08\right.$ unit $^{-1}$ day $\left.^{-1}\right)$ on the first date of sowing followed by the second $\left(0.068\right.$ unit $^{-1}$ day $^{-1}$ ) date of sowing. As far as AUDPC was concerned, 
Table 3: Effect of sowing dates on the progression of bacterial spot in pumpkin

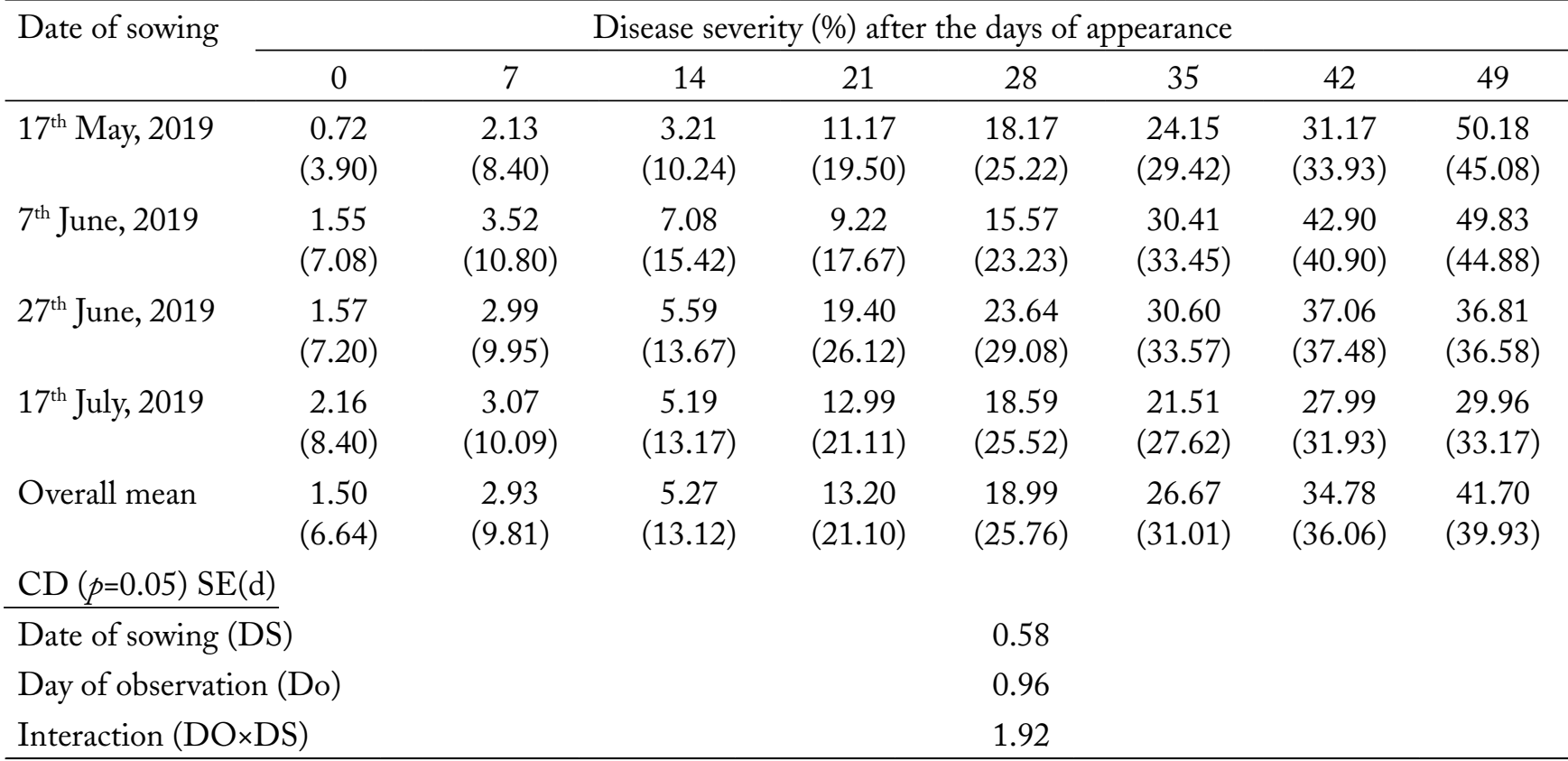

Table 3: Continue...

\begin{tabular}{|c|c|c|c|c|c|c|}
\hline \multirow[t]{2}{*}{ Date of sowing } & \multicolumn{6}{|c|}{ Disease severity (\%) after the days of appearance } \\
\hline & 56 & 63 & 70 & $\begin{array}{c}\text { Overall } \\
\text { mean }\end{array}$ & $\begin{array}{l}\text { Apparent infection rate } \\
\quad\left(\text { unit }^{-1} \text { day }^{-1}\right)\end{array}$ & AUDPC \\
\hline 17 $7^{\text {th }}$ May, 2019 & $\begin{array}{c}60.43 \\
(51.03)\end{array}$ & $\begin{array}{c}68.46 \\
(55.81)\end{array}$ & $\begin{array}{c}79.22 \\
(62.85)\end{array}$ & $\begin{array}{c}31.73 \\
(31.40)\end{array}$ & 0.089 & 21.53 \\
\hline $7^{\text {th }}$ June, 2019 & $\begin{array}{l}55.67 \\
(48.23)\end{array}$ & $\begin{array}{c}61.04 \\
(51.36)\end{array}$ & $\begin{array}{c}63.35 \\
(52.72)\end{array}$ & $\begin{array}{c}30.92 \\
(31.43)\end{array}$ & 0.068 & 21.52 \\
\hline $27^{\text {th }}$ June, 2019 & $\begin{array}{c}44.66 \\
(41.92)\end{array}$ & $\begin{array}{c}46.62 \\
(43.04)\end{array}$ & $\begin{array}{c}48.75 \\
(44.27)\end{array}$ & $\begin{array}{l}27.06 \\
(29.35)\end{array}$ & 0.055 & 22.27 \\
\hline $17^{\text {th }}$ July, 2019 & $\begin{array}{c}31.66 \\
(34.84)\end{array}$ & $\begin{array}{c}33.02 \\
(35.06)\end{array}$ & $\begin{array}{c}35.33 \\
(36.45)\end{array}$ & $\begin{array}{l}20.13 \\
(25.16)\end{array}$ & 0.047 & 14.30 \\
\hline Overall mean & $\begin{array}{c}48.11 \\
(43.84)\end{array}$ & $\begin{array}{c}52.29 \\
(46.32)\end{array}$ & $\begin{array}{c}56.66 \\
(49.07)\end{array}$ & & & \\
\hline \multicolumn{7}{|l|}{$\mathrm{CD}(p=0.05) \mathrm{SE}(\mathrm{d})$} \\
\hline Date of sowing (DS) & \multicolumn{4}{|c|}{0.29} & & \\
\hline Day of observation (Do) & \multicolumn{4}{|c|}{0.48} & 0.002 & 0.11 \\
\hline Interaction $(\mathrm{DO} \times \mathrm{DS})$ & \multicolumn{4}{|c|}{0.97} & & \\
\hline
\end{tabular}

Figures in parentheses are arcsine transformed values

it was significantly minimum (14.30) on the fourth date of sowing followed by the third (19.41) date of sowing. However, a maximum (21.53) AUDPC was recorded on the first date of sowing which was statistically at par with AUDPC in the second (21.52) date of sowing.

The data presented in Table 4 reveal the number of fruits harvested and fruit yield $(\mathrm{kg})$ of pumpkin vine ${ }^{-1}$ in plants sown on four different dates. It is clear from the table that no disease symptoms were observed on any of the pumpkin fruits. However, the number of fruits harvested was definitely affected due to disease symptoms observed in leaves. The total number of fruits harvested and yield vine $^{-1}$ in the case of pumpkin was significantly maximum in plants sown on $17^{\text {th }}$ July (14.31 and $9.59 \mathrm{~kg}$ ) followed by 


\begin{tabular}{lccc}
\hline $\begin{array}{l}\text { Table 4: Effect of different dates of sowing on fruit yield } \\
\text { of pumpkin }\end{array}$ & \multicolumn{3}{c}{} \\
\hline Date of sowing & $\begin{array}{c}\text { Disease } \\
\text { incidence } \\
(\%)\end{array}$ & $\begin{array}{c}\text { Total no. of } \\
\text { fruits harvested } \\
\text { vine }^{-1}\end{array}$ & $\begin{array}{c}\text { Actual } \\
\text { yield }(\mathrm{Kg}) \\
\text { vine }^{-1}\end{array}$ \\
\hline $17^{\text {th }}$ May, 2019 & 0.00 & 11.67 & 7.51 \\
$7^{\text {th }}$ June, 2019 & 0.00 & 12.20 & 8.24 \\
$27^{\text {th }}$ June, 2019 & 0.00 & 13.31 & 8.97 \\
$17^{\text {th }}$ July, 2019 & 0.00 & 14.31 & 9.59 \\
SE(d) & & 0.22 & 0.13 \\
CD $(p=0.05)$ & & 0.48 & 0.28 \\
\hline
\end{tabular}

those sown on $27^{\text {th }}$ June (13.31 and $\left.8.97 \mathrm{~kg}\right), 7^{\text {th }}$ June (12.20 and $8.24 \mathrm{~kg}$ ) and $17^{\text {th }}$ May (11.67 and $\left.7.51 \mathrm{~kg}\right)$.

The results in pumpkin crop were similar to those recorded in bottle gourd except that no incidence of disease was recored on pumpkin fruits. However, as far as yield of pumkin crop was concerned, it was found to be maximum in mid July ( $17^{\text {th }}$ July) sown crop and minimum in mid may (17 $7^{\text {th }}$ May) sown crop. There was a clear cut relationship in the disease levels and crop yield. The results of present studies are supported by Mohammed et al. (2003) who concluded that incidence of bacterial blight of cotton decreased with delayed sowing. Another similar observation was recorded by Amin et al. (2017) who reported that to escape the crop from the bacterial blight of cluster bean, sowing time played a vital role as non-monitory input and found that per cent disease severity of bacterial blight was decreased significantly with each delay in sowing and early sowing i.e. third and fourth week of July resulted in increased disease intensity significantly.

\section{CONCLUSION}

$\mathrm{D}$ isease severity decreased with delay in the date of sowing from $17^{\text {th }}$ May to $17^{\text {th }}$ July in both the crops. High disease severity was recorded in $17^{\text {th }}$ May and $7^{\text {th }}$ June sown crops. The apparent infection rate was also lesser in late sown crops. Expected yield loss was also minimum in late June and mid July sown crops as the disease affects the plant foliage thus reducing the photosynthetic area, ultimately leading to lesser fruit production.

\section{REFERENCES}

Alippi, A.M., 1989. Characterization of Xanthomonas campestris pv. cucurbitae causal agent of bacterial leaf spot of squash. Argentina magazine de Microbiologica 21(1), 15-19.

Altin, I., Casoli, L., Stefani, E., 2020. First report of bacterial spot caused by Xanthomonas cucurbitae on pumpkin in Italy. New Disease Reports 41, 21. http:// dx.doi.org/10.5197/j.2044-0588.2020.041.021.

Amin, A.M., Patel, N.R., Jaiman, R.K., Prajapati, D.B. Amin, A.U., 2017. Effect of date of sowing on the development of bacterial blight of cluster bean. Environment and Ecology 35(2), 967-970.

Anonymous, 1975. Vegatables. Australia, Queens land Department of Primary Industries: Annual Report 1974-75, 51p.

Babadoost, M., 2012. Report on plant disease. Department of Crop Sciences, University of Illinois at Urbana Campaign. Available at http://extension.cropsciences. illinois.edu/fruitveg/pdfs/949_bacterial_spot.pdf. Accessed on January, 2021

Babadoost, M., Ravanlou, A., 2012. Outbreak of bacterial spot (Xanthomonas cucurbitae) in pumpkin fields in Illinois. Plant Disease 96,1222.

Babadoost, M., Zitter, T.A., 2009. Fruit rots of pumpkin a serious threat to the pumpkin industry. Plant Disease 93, 772-782.

Bryan, M.K., 1930. Bacterial leaf spot of squash. Journal of Agricultural Research 40(4), 385-391.

Dhaliwal, M. S., 2017. $3^{\text {rd }}$ ed. Handbook of Vegetable Crops.Kalyani Publishers, New Delhi, 358p.

Dutta, B., Gitaitis, R.D., Lewis, K.J., Langston, D.B., 2013. A new report of Xanthomonas cucurbitae causing bacterial leaf spot of watermelon in Georgia, USA. Plant Disease97,556.

Goldberg, N., 2012. Bacterial leaf spot of cucurbits fact sheet, plant pathology: The news you can use. New Mexico State University Extension Bulletin, October, 2012. Available at https://aces.nmsu.edu/ ces/plantclinic/documents/bacterial-leaf-spot-ofcucurbits.pdf. Accessed on January, 2021

Jarial, K., Dogra, B.S., Mandradia, R.K., Kumar, S., Sharma, D., Gupta, A.K., 2011. Investigations on a new bacterial disease of bottle gourd in sub-tropical zone of Himachal Pradesh. Plant Disease Research 26(1), 68-75.

Jarial, K., Jarial, R.S., Sharma, D., Dogra, B.S., Kumar, S., 2015. Strategy for the management of bacterial spot of bottle gourd caused by Xanthomonas cucurbitae under low hill conditions of Himachal Pradesh. International Journal of Bio-resource and Stress Management 6(6), 744-748.

Jarial, K., Jarial, R.S., Sharma, M., Kumari, S., 2018. Bacterial leaf spot (Xanthomonas cucurbitae): an emerging threat for cucurbit cultivation in sub tropical zone of Himachal Pradesh. Technology Notes, Himalayan Phtopathological Society, Dr Y S Parmar University of Horticulture and Forestry, Nauni, Solan, 5-6.

Jhonston, A., Booth, C., 1983. Plant pathologist's 
pocketbook. $2^{\text {nd }}$ Ed. Commonwealth Mycological Institute, Kew. 439 p.

Jurgens, A.G., Babadoost, M., 2013. Sensitivity of Erwinia amylovora in Illinois orchard to streptomycin, oxytetreacycline, kasugamycin, and copper. Plant Disease 97, 1484-1490.

Raut, S.A., Ingole, O.V., Kolhe, A.V., 2010. Influence of sowing dates on incidence and intensity of bacterial blight of cotton caused by Xanthomonas axonopodis pv. malvacearum. Journal of Plant Disease Sciences 5(1),110-112.

Lamichhane, J.R., Varvaro, L., Balestra, G.M., 2010. Bacterial leaf spot caused by Xanthomonas cucurbitae reported on pumpkin in Nepal. New Disease Reports $22,20$.

Larazev, A.M., 2009. Diseases: Xanthomonas campestris pv. Cucurbitae (Bryan) Dye-bacterial leaf spot of cucurbits. In: 2003-2009 Project "Interactive agricultural ecological Atlas of Russia and neighbouring countries: economic plants and their diseases, pests and weeds". Available at http://www.agroatlas.ru/en/content/ diseases/Cucurbitae/Cucurbitae_Xanthomonas_ campestris_pv_cucurbitae/Accessed on January, 2021

Li, Y.H., 1990. Identification of the pathogen of bacterial leaf spot of cucumber. Acta Phytopathologica Sinica 20(2), 146.

Liu, Q., Ravanlou, A., Babadoost, M., 2016. Occurrence of bacterial spot on pumpkin and squash fruit in the north central region of the United States and bacteria associated with the spots. Plant Disease 100, 2377-2382.

Maringoni, A.C., Leite, R.P.J., Komori, N., 1988. A new disease of cucumber (Cucumis sativus L.) caused by Xanthomonas campestris pv. cucurbitae (Bryan) Dye in Brazil. Summa Phytopathologica 14, 225-230.

McKinney, H.H., 1923. Influence of soil temperature and moisture on infection of wheat seedlings by Helminthosporium sativum. Journal of Agricultural Research 26, 195-217.

Mohammed, O.E., Ahmed, N.E., Eneji, A.E., Ma, Y.Q., Ali, E., Inanaga, S., Sugimoto, Y., 2003. Effect of sowing dates on the incidence of bacterial blight and yield of cotton. Basic and Applied Ecology 4(5), 433-440.

Pruvost, O., Robene-Soustrade, I., Ah-You, N., Jouen, E., Boyer, C., Wuster, G., Hostachy, B., Napoles, C., Dogley, W., 2009. First report of Xanthomonas cucurbitae causing bacterial leaf spot of watermelon in Seychelles. Plant Disease 93(6), 671.
Rafi, A., Hameed, A., Akhtar, A.M., Akmal, M., Bibi, A., Ali, M., Rahman, H., Junaid, M., 2013. Effect of planting dates on bacterial leaf blight incidence and yield performance of rice cultivars in different location of Khyber Pakhtunkhwa. Pakistan. Sarhad Journal of Agriculture 29(3), 407-408.

Raut, S.A., Ingole, O.V., Kolhe, A.V., 2010. Influence of sowing dates on incidence and intensity of bacterial blight of cotton caused by Xanthomonas axonopodis pv. malvacearum. Journal of Plant Disease Sciences 5(1), 110-112.

Robbs, C.F., Kumura, D., Barbosa, G.A.A., 1972. Bacterial blight of squash, a disease new to Brazil. Archives of the Federal Rural University of Rio de Janeiro 2(2), 105-106.

Salamanca, L.R., 2014. Bacterial diseases of pumpkins: an old enemy and an emerging bacterial disease. Michigan State University Extension Bulletin. Available at https://www.canr.msu.edu/news/bacterial_diseases_ of_pumpkins_an_old_enemy_and_an_emerging bacterial_disea. Accessed on January, 2021

Sundin, G. W., Castiblanco, L. F., Yuan, X., Zeng, Q. Yang, C.H., 2016. Bacterial disease management:challenges, experience, innovation and future prospects: challenges in bacterial molecular plant pathology. Molecular Plant Pathology 17(9), 1506-1518.

Trueman, C.L., Roddy, E., Goodwin, P.H., 2014. First report of bacterial spot (Xanthomonas cucurbitae) of pumpkin in Ontario, Canada. New Disease Reports $30,8$.

Shanner, G., Finney, R.E., 1977. The effect of nitrogen fertilization on the expression of slow mildewing resistance in knox wheat. Phytopathology 67, 1051-1056.

Sinha, P.P., 1989. Preliminary studies on bacterial leaf spot of cucumber. Indian Phytopathology 42, 146-149.

Taketani, K., Tamura, M., Wakimoto, S., 1976. Studies on fruit spot of prince melon III: scab like spots caused by Xanthomonas cucurbitae (Bryan) Dowson. Proceedings of the Association for Plant Protection of Hokuriku 24, 63-67.

Van der Plank, J.E., 1963. Plant disease: epidemics and control. Academic Press, New York, 349 p.

Vauterin, L., Hoste, B., Kersters, K., Swings, J., 1995. Reclassification of Xanthomonas. International Journal of Systematic Bacteriology 45, 472-489.

William, R.H., Zitter, T.A., 1996. Bacterial leaf spot: compendium of cucurbits diseases. American Phytopathological Society, St. Paul M N, 35 p. 